\title{
Categorizing the IS Research Literature: A User Oriented Perspective
}

\author{
B. Jayatilaka, H. K. Klein and J. Lee \\ School of Management, \\ State University of New York at Binghamton \\ Binghamton, NY, USA
}

\section{ibandula@binghamton.edu hkklein@binghamton.edu ylee@binghamton.edu}

\begin{abstract}
The predecessors of this research project were the efforts to classify the Information Systems (IS) research along paradigmatic lines. While the paradigmatic classifications are very useful philosophically, examination of an issue such as the use of Information Systems and the related socioorganizational issues require a classification that is centered around the social phenomenon of the use and effects of IS. Our approach to the categorization of the body of knowledge captured in the existing Information Systems literature can make the contributions to the use side of Information Systems more explicit. The new twist of this approach is that it provide an integrative perspectives on IS use by seeking to bridge the most prevalent divides currently fragmenting the IS literature. We call our proposal for a new approach to literature classification "substance oriented", because it follows neither the latest paradigmatic classification nor earlier bottom up citation or key word based literature classification schemes. Instead it explicitly builds on social theory concepts directly relevant for the "user-domain" and is in this sense "substance-oriented", at least at its highest level. In its current version, the paper identifies the core concepts of Gidden's Structuration Theory (ST) as being relatively most suited for capturing user concerns in the existing archival body of IS research publications.
\end{abstract}

\section{Presentation Outline}

1. Objective: Categorize existing IS literature using a social theory that can cut across the present paradigmatic camps

2. Past classifications:

a. Multi-paradigmatic classifications - such as the ones (Hirschheim et al. 1996) based on Burrell and Morgan framework

Material published as part of this publication, either on-line or in print, is copyrighted by the Informing Science Institute. Permission to make digital or paper copy of part or all of these works for personal or classroom use is granted without fee provided that the copies are not made or distributed for profit or commercial advantage AND that copies 1 ) bear this notice in full and 2) give the full citation on the first page. It is permissible to abstract these works so long as credit is given. To copy in all other cases or to republish or to post on a server or to redistribute to lists requires specific permission and payment of a fee. Contact Publisher@InformingScience.org to request redistribution permission. b. Single-paradigmatic classifications - such as Barki et al. (1988) and Ives et al. (1980)

c. Deetz $(1994,1996)$ classification - replacing subjective-objective dimension of Burrell and Morgan framework. 
3. Need for an integrative framework that can cut across multiple paradigms

4. We propose that using a framework that allows us to examine the social phenomena in IS use will allow us to classify the IS literature to focus on the use side of IS
a. Giddens Structuration Theory (ST)
b. Results of sample classifications

5. Limitations of the classification - limitations imposed by the original basis for classification, i.e., Gidden's Structuration Theory.

6. Benefits of the classification - possibility of identification of:

a. the under researched areas

b. the relationships between certain theoretical foundations and aspects of IS use they focus on. 